\title{
The Journal of
}
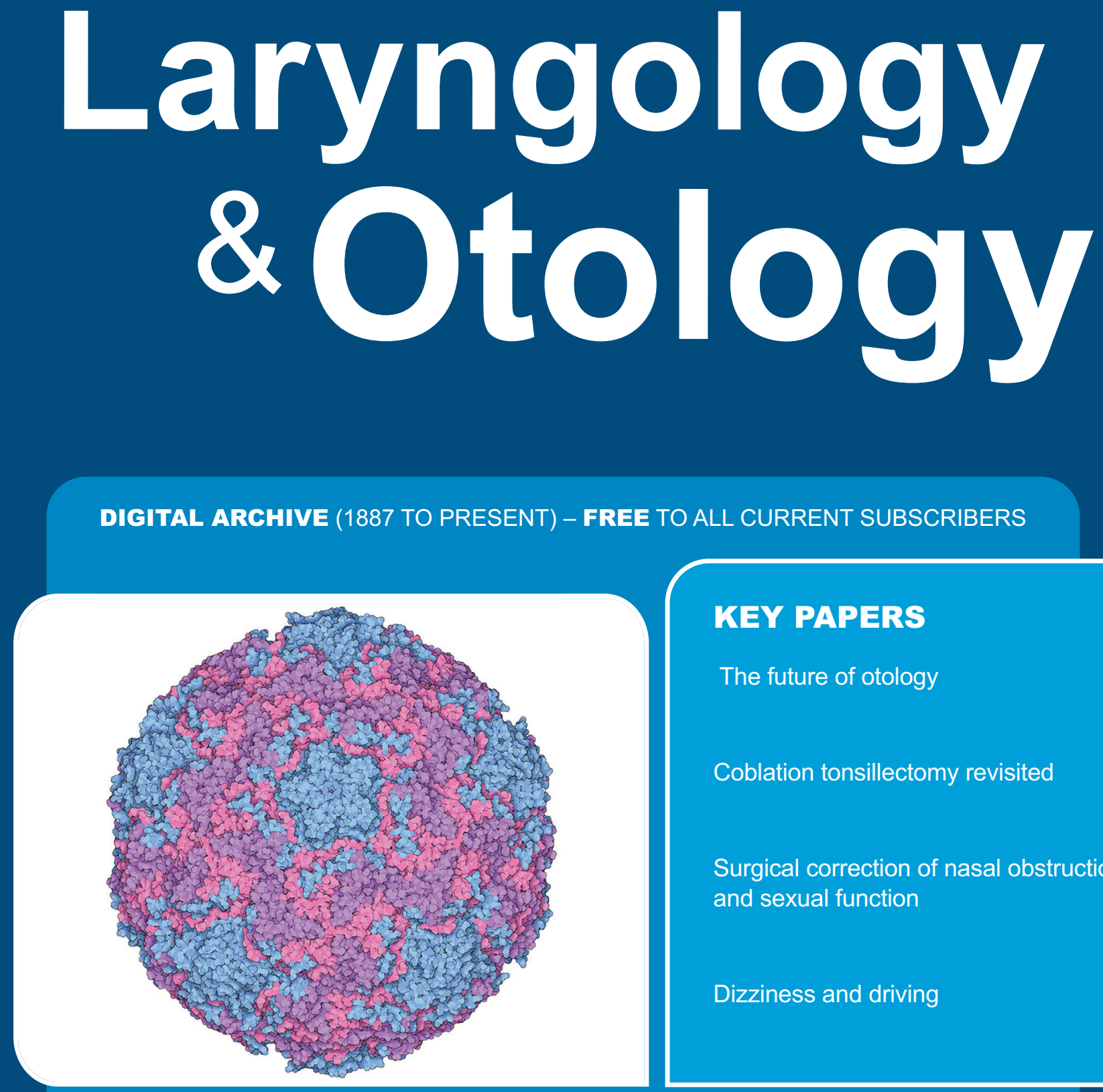

\section{KEY PAPERS}

The future of otology

Coblation tonsillectomy revisited

Surgical correction of nasal obstruction and sexual function

Dizziness and driving

The sternocleidomastoid flap in head and neck surgery

Reducing cicatricial stenosis after canalplasty for auditory exostoses

Elective neck dissection for the node-negative neck during salvage laryngectomy

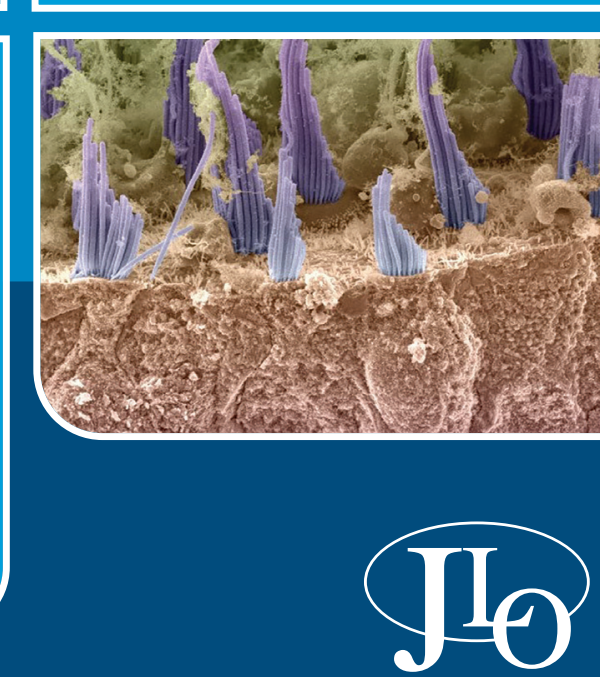

Endoscopic posterior nasal neurectomy 

Cambridge University Press

The Cambridge Medicine programme focuses its book publishing in a defined set of core clinical areas with our great strength in the clinical brain sciences. Other specialties of significant focus include reproductive medicine/obstetrics and gynaecology, anaesthesia and critical care, emergency medicine and pathology.

Our journals programme covers a broad spectrum of medical disciplines including emergency and disaster medicine, epidemiology and infectious diseases, biomedical science, genetics, nutrition, mental health and psychiatry, and neuroscience.

We partner with many learned societies including The Society for Healthcare Epidemiology of America, and the Neuroscience Education Institute, and the Royal College of Obstetricians and Gynaecologists.

For further details visit:

cambridge.org/core-medicine 
The Journal of

\section{Laryngology \& Otology}

Founded in 1887 by Morell Mackenzie and Norris Wolfenden

\section{Editors}

Edward Fisher (Birmingham)

S S Musheer Hussain (Dundee)

Jonathan Fishman (London)

\section{Emeritus Editor}

Robin Youngs (Gloucester)

\section{Book Review Editor}

Liam Flood (Middlesbrough)

\section{Senior Assistant Editors}

Quentin Gardiner (Dundee)

Vinidh Paleri (London)

\section{Assistant Editors}

Kim Ah-See (Aberdeen)

Jon Bennett (Plymouth)

Abir Bhattacharyya (London)

Brian Bingham (Glasgow)

Sean Carrie (Newcastle)

Jayesh Doshi (Birmingham)

Charlie Hall (Gloucester)

Omar Hilmi (Glasgow)

Claire Hopkins (London)

Richard Irving (Birmingham)

Hisham Khalil (Plymouth)

Bhik Kotecha (London)

Tristram Lesser (Liverpool)

Ann-Louise McDermott (Birmingham)

Paul Nankivell (Birmingham)

\author{
Prepageran Narayanan (Kuala Lumpur) \\ Desmond Nunez (Vancouver) \\ Srinivasa Raghavan (Guildford) \\ Peter Robb (Epsom) \\ Mark Samaha (Quebec) \\ Riaz Seedat (Bloemfontein) \\ Azhar Shaida (London) \\ Patrick Spielmann (Dundee) \\ lain Swan (Glasgow) \\ Vik Veer (London) \\ John Watkinson (Birmingham) \\ Richard Wight (Middlesbrough) \\ Tim Woolford (Manchester)
}

\section{Advisers in Audiology}

David Baguley (Nottingham)

\section{Advisers in Pathology}

Simon Rose (Bath)

Ketan Shah (Oxford)

Adrian Warfield (Birmingham)

\section{Adviser in Statistics}

Simon Ogston (Dundee)

\section{Website Editor}

Stephen Jones (Dundee)

\section{Managing Editor}

Rosamund Greensted

Cover images: (Upper left) Rhinovirus. Credit: David S. Goodsell, RCSB Protein Data Bank. Wellcome Images. (Lower right) Hair cells in the utricle. Credit: Dr David Furness. Wellcome Images.

Editorial Office: Maybank, Quickley Rise, Chorleywood, Herts WD3 5PE, UK.

Tel: +44 (0)1923 283561. Email: j.1.o@btconnect.com. Website: http://www.jlo.co.uk

The Journal of Laryngology \& Otology (ISSN 0022-2151) is published monthly in both print and electronic form and distributed on behalf of the proprietors, JLO (1984) Ltd, by Cambridge University Press Registered Charity No 293063 


\section{SUBSCRIPTIONS, LICENSING, ADVERTISING AND REPRINTS}

The Journal of Laryngology \& Otology (ISSN 0022-2151) is published monthly in both print and electronic form and distributed on behalf of the proprietors, JLO (1984) Ltd, by Cambridge University Press.

\section{Subscriptions: Volume 133, 2019 (Monthly)}

Both standard and online-only subscription prices entitle subscribers to access all of the archival online content, which dates back to Volume 1 (1887). For further details please go to Cambridge University Press.

Institutions print and electronic: $£ 646 / \$ 1289$. Institutions electronic only: $£ 512 / \$ 1022$. Individuals print plus electronic: $£ 324 / \$ 649$. Member rates available - please enquire. Special rates available for Trainees. Print ISSN 0022-2151. Electronic ISSN 1748-5460.

Orders are regarded as firm, and payments are not refundable. All orders and enquiries, including online licensing and consortia enquiries, should be sent to: Journals Subscription Department, Cambridge University Press.

*Periodicals postage paid at Rahway, NJ. US Postmaster: send address changes to The Journal of Laryngology \& Otology, c/o Mercury Airfreight International Ltd, 365 Blair Road, Avenel, NJ 07001, USA.

\section{Advertising sales}

Contact: Ad sales, Journals, Cambridge University Press.

Tel: +44 (0)1223 325757

Fax: +44(0)1223 325801

E-mail: UK: ad_sales@cambridge.org

US: USAdSales@cambridge.org

Other business correspondence

All other business correspondence, should be sent to: Daniel Edwards dedwards@cambridge.org Journals Department, Cambridge University Press. Enquiries about reprints should be sent to Ad sales: special_sales@cambridge.org

\section{2019 JLO (1984) Limited}

Apart from any fair dealing for the purposes of research or private study, or criticism or review, as permitted under the UK Copyright, Designs and Patents Act, 1988, no part of this publication may be reproduced, stored, or transmitted, in any form or by any means, without the prior permission in writing of the Editors, or in the case of reprographic reproduction in accordance with the terms of licences issued by the Copyright Licensing Agency in the UK, or in accordance with the terms of licences issued by the appropriate Reproduction Rights Organization outside the UK. Enquiries concerning reproduction outside the terms stated here should be sent to the publishers at the above address. Contributors and advertisers are responsible for the scientific content and the views expressed, which are not necessarily those of the Editors or of Cambridge University Press.

Typeset by Techset and printed in the UK by Bell \& Bain Ltd.

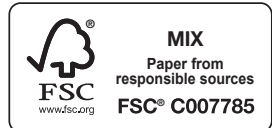

This Journal issue has been printed on $\mathrm{FSC}^{\mathrm{TM}}$-certified paper and cover board. FSC is an independent, non-governmental, not-for-profit organization established to promote the responsible management of the world's forests. Please see www.fsc.org for information.

\section{SUMMARY GUIDANCE FOR AUTHORS}

The Journal of Laryngology \& Otology $(J L O)$ is a peer-reviewed publication, and is indexed/abstracted in most major databases including Index Medicus, MEDLINE/ PubMed, Science Citation Index, Current Contents and EMBASE.

Only a very brief summary of the submission requirements is presented here: when preparing their manuscripts, authors must consult and comply with the full Instructions for Authors on the $J L O$ website at http://www.jlo.co.uk/docs/submittingarticles.htm Adherence to these will speed up the editorial process.

All contributions are considered for publication on the understanding that they have been submitted solely to the $J L O$ and that they have not previously been published. Contributions in the following categories will be considered: Main Articles (reporting clinical research or audit), Review Articles, Historical Articles, Short Communications (including 'How I do it'), Clinical Records (case reports), and Letters to the Editors.

\section{Submission}

All contributions must be accompanied by a covering letter, which must be signed by all authors. Manuscripts should be submitted to the Editors:

- either online via www.jlo.co.uk

- or by post to the Editorial Office, The Journal of Laryngology \& Otology, Maybank, Quickley Rise, Chorleywood, Hertfordshire WD3 5PE, UK (Tel/Fax: +44 (0)1923 283561; E-mail j.1.o@) btconnect.com). One copy should be submitted together with a copy on a USB stick (including separate TIFF files of any figures) and two printed on paper (together with two sets of figures).

The text of the manuscript (incorporating all tables and the figures legends, but not the figures themselves) must be saved as a Microsoft Word document or an RTF file (i.e. 'rich text format'). Use double-spaced, unjustified text throughout. The title page must contain the full title of the paper; the names and qualifications of all authors; the departments(s) and institution(s) where the work was carried out; and the name, postal and e-mail address, and telephone and fax numbers of the author responsible for all communications about the manuscript and proofs. An Abstract (maximum 150 words) and Key words must be provided for all contributions (except Letters).

References should be identified in the text by superscript Arabic numerals and listed at the end of the manuscript in the order in which they are first cited in the text. The tables feature of the word processor should be used to prepare Tables, and both these and the list of Figure legends should appear on separate pages at the end of the manuscript. All Figures must be saved as separate TIFF files at a resolution of $600 \mathrm{dpi}$.

The authors of all material accepted for publication will be required to assign copyright to JLO (1984) Ltd; a form for this purpose and for ordering offprints will accompany the proofs. The proofs will be sent by e-mail to the corresponding author as a PDF file, and should be corrected and returned within three working days. 